\title{
Social Problems as Sources of Opportunity: Antecedents of Social Entrepreneurship Opportunities
}

\author{
Agnieszka Żur
}

\begin{abstract}
A B S T R A C T
Objective: Based on extensive literature review, this paper aims to establish if, why and how, in given environmental and market contexts, social entrepreneurship (SE) opportunities are discovered and exploited. It positions social problems as sources of entrepreneurial opportunity. The article presents an integrated process-based view of SE opportunity antecedents and concludes with a dynamic model of SE opportunity.

Research Design \& Methods: To fulfil its goal, the paper establishes opportunity as unit of research and explores the dynamics of opportunity recognition. To identify the components of SE opportunity through a process-based view, the study follows the steps of critical literature review method. The literature review follows with logical reasoning and inference, which results in the formulation of a model proposition of social entrepreneurship opportunity.
\end{abstract}

Findings: The paper presents a holistic perspective on opportunity antecedents in SE context and introduces social problems, information, social awareness and entrepreneurial mindset as fundamental components of social entrepreneurship opportunity equation.

Implications \& Recommendations: It is necessary to remember for policy makers, investors and partners involved within the social sector, that social problems can be the source of entrepreneurial opportunity. Training, assisting and engaging socially aware entrepreneurs is a promising line of development for all communities.

Contribution \& Value Added: The major contribution of this study lies in extending the existing body of social entrepreneurship research by providing a new perspective, placing social problem as opportunity in the centre of the discussion.

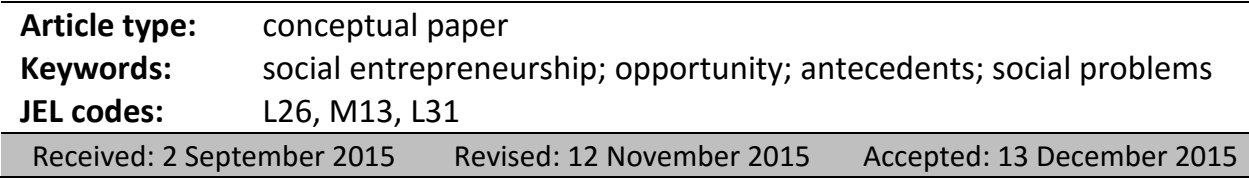

\section{Suggested citation:}

Żur, A. (2015). Social Problems as Sources of Opportunity: Antecedents of Social Entrepreneurship Opportunities. Entrepreneurial Business and Economics Review, 3(4), 73-87. doi: 


\section{INTRODUCTION}

Social enterprises function at the intersection of various economic sectors in different legal forms, either for-profit, non-profit or not-for-loss, often in multiple organisational forms simultaneously (Battilana \& Lee, 2014). Social entrepreneurship has been recognized in the last two decades by numerous authors as a successful pathway of tackling world's both local and global social problems (Dees, 2007; Curtis, 2007; Short et al., 2009). Their fundamental objective is profound and lasting structural social change (Praszkier \& Nowak, 2012, p. 64). Social enterprises use economic means to introduce social change and thus transform market, human and social resources into social capital (Stryjan, 2004).

Most social entrepreneurship conceptualizations are broad and inclusive in character, which is why scholars emphasize the need to deepen our understanding of social entrepreneurship phenomena, "to bridge the gap between our current understanding of social entrepreneurship and an enhanced knowledge that could aid in researching this emerging field" (Short et al., 2009, p. 162). Researchers have identified numerous exploration avenues to narrow that gap and one of them is the identification of opportunities pursued by social enterprise to fulfill their social goals (Bull, 2008; Short et al., 2009). This research is an answer to that call.

All forms of entrepreneurship require exploration of both micro level (socio-cognitive, emotional) and macro level (institutional, environmental) antecedents (Battilana, 2006). This study adapts a holistic view and takes the entrepreneurial opportunity lens to social entrepreneurship, since the notion of opportunity creation, recognition and exploitation are traditionally associated with entrepreneurship.

Understanding the nature of opportunities is important because it can enhance our understanding of the origins and distinctive features of all entrepreneurial acts. Authors have noted that research focus strictly on the firm, may be useful for some domains such as strategic entrepreneurship which compares performance between competitive firms, but it does not add enough insight into the entrepreneurship nexus (Shane \& Venkataraman, 2000). Opportunity as unit of analysis in entrepreneurship research allows the assessment of entrepreneurial acts and provides a deeper understanding of its dynamics. Social entrepreneurship as an entrepreneurial act is always a response to perceived opportunity and as such requires an opportunity-based approach as well. Therefore opportunity as unit of analysis is much advised.

The main goal of this paper is to present an opportunity-based view (OBV) of social entrepreneurship, the antecedents and conceptualization of this stream of theory, claiming that OBV provides a useful lens for social entrepreneurship activity analysis. The study is based on an integrative literature review, combining sources from fields of general entrepreneurship theory devoted to opportunity, social entrepreneurship theory and social problems theory. The paper starts with introducing social enterprises, their hybrid nature and various tensions. Then it turns to opportunity as unit of analysis, just as a significant bulk of entrepreneurship theory does. It explores the antecedents of opportunity development to sum up with a proposal of a research model. The major contribution of this study lies in extending the existing body of social entrepreneurship research providing a new perspective on opportunity identification and exploitation modes in SE context. 


\section{MATERIAL AND METHODS}

Social entrepreneurship (SE) has emerged as an important area of research and practice as sub-stream of entrepreneurship research. Parallel to that social problems research has been growing in scope contributing largely to the development of social entrepreneurship theory.

The focus of this study is on the discussion and elaboration of social entrepreneurship opportunity concept. In its main objective it aims to identify the necessary components of opportunity in SE context through a process-based view. The leading method employed in this study is integrative literature review.

Scientific research requires a procedure according to pre-determined steps in order to obtain the most valuable cognitive effects of the research process (Babbie, 2012, pp. 112-113). The nature of the study is multidimensional, it realises exploratory, descriptive, analytical and predictive purposes. The thorough literature study was prepared in order to conceptualise and operationalise the research objective. A five-stages model of a integrative literature review was employed in this study (Table 1). The study relied on literature sources from EBCSO and EMERALD scholarly articles data base, as well as classical works in the relative fields. Through the process depicted below and application of chosen keywords a total of 159 articles of selected, of which 78 were included for further analysis and 44 were included in the final version of the paper as reference points.

Table 1. Methodological background of the research process

\begin{tabular}{|c|c|c|}
\hline No. & Steps & Specification \\
\hline 1. & Searching for literature & $\begin{array}{l}\text { - Keywords: social entrepreneurship, oppor- } \\
\text { tunity, social problem, social enterprise } \\
\text { - Defining inclusion criteria }\end{array}$ \\
\hline 2. & $\begin{array}{l}\text { Screening and mapping the litera- } \\
\text { ture }\end{array}$ & $\begin{array}{l}\text { - Identifying main definitions } \\
\text { - contrasting existing conceptualizations } \\
\text { - Evaluating applicability } \\
\text { - Excluding and including identified sources }\end{array}$ \\
\hline 3. & Assessing the literature & $\begin{array}{l}\text { - Full text review based on inclusion criteria } \\
\text { - } \text { Critical review of arguments } \\
\text { - Identifying competing and completing argu- } \\
\text { ments } \\
\text { - Comparing and evaluating arguments }\end{array}$ \\
\hline 4. & Integrating the literature sources & $\begin{array}{l}\text { - Identifying contradictions } \\
\text { - Identifying gaps } \\
\text { - Drawing conclusions }\end{array}$ \\
\hline 5. & Final inference & - Model formulation \\
\hline
\end{tabular}

Source: own evaluation based on (Whittemore \& Knafl, 2005).

The literature review was followed by logical reasoning and inference, which resulted in the formulation of the proposed process-based view model of social innovation. 


\section{LITERATURE REVIEW AND THEORY DEVELOPMENT}

\section{Social Entrepreneurship: Conceptual Challenges and Tensions}

Social entrepreneurship (SE) has emerged as an important area of research and practice. Social entrepreneurship has been recognized in the last two decades by numerous authors as a successful way of transforming the social sphere by addressing both local and global social problems (Dees, 2007; Short et al., 2009; Yunus, 2011; Praszkier \& Nowak, 2012). Social entrepreneurship had been defined in the past as a process of employing marketbased methods to solve social problems (Grimes et al., 2013). By blending initiative, innovativeness, community involvement and resource mobilization, social enterprises introduce solutions that can work more effectively than state or charity standard approaches. effectively. Their advantage over government programs is autonomy, flexibility and access to private resources (Dees, 2007). The primary advantage over charity lies in the problemsolving nature rather than providing aid nature of these organisations (Yunus, 2011). The increasing popularity of social enterprise has also resulted in regulatory activity aimed at supporting the development of a social enterprise field. For example, new legal forms have been created in order to better address the needs of social enterprises that are neither typical corporations nor typical not-for-profits. Yet new research is still needed. In spite of twenty years of research, it still remains fragmented and polyphonic.

Because definitions of SE have been developed in different domains (non-profit, forprofit and public sectors) a unified definition has not emerged. There are however certain features of SE phenomena that form the foundation of this research area, delineate its boundaries and lay foundations for definitions:

- first, they extend the "opportunity exploitation logic" of entrepreneurship onto the social sphere (Praszkier and Nowak, 2012, p. 52);

- second, they blend social and financial objectives (Dees, 2007), yet the generated profit serves merely as a mean of extending the social value added (Yunus, 2011, p. 47);

- third, all coexisting conceptualizations of social enterprises refer to the ability of leveraging resources to address social problems (Dart, 2004).

And thus social entrepreneurship has been described in the past as "an innovative, social-value creating activity that can occur within or across the non-profit, business or government sector" (Stevenson et al., 2007, p. 4) or as a "process of creating social value by exploring and exploiting opportunities and combing resources in new ways" (Mair \& Marti, 2006, p. 37). Both these popular definitions are overlapping and completing in nature, referring to the essence of entrepreneurship, yet cannot serve as clear guidelines for SE recognition.

EMES (Emergence of Social Enterprises in Europe) criteria have been often adapted in past research, as clear and comprehensive (Defourny \& Nyssens, 2010, pp. 32-53). The economic criteria outlined by EMES are: (i) commercial activity of selling goods or services, (ii) independence form government administration, (iii) undertaking economic risk, and (iv) employing paid labour. The social criteria are: (i) centrality of social mission, (ii) citizen and community rooted, (iii) participative in character, (iv) democratic governance and (v) limited profit distribution. 
The fundamental difference between traditional and social entrepreneurship is the primacy of goals. Traditional entrepreneurs through opportunity identification and exploitation seeks to achieve economic commercial goals and generate economic market value added. Social entrepreneurs through the same processes seeks to achieve social goals and generate social value added. Both types of entrepreneurs are characterized by proactive attitudes, the will to change the current state of equilibrium, and readiness to bear calculated risk. Both entrepreneurs hold an entrepreneurial mindset, which has been categorized in the past as the passionate seeking of new opportunities (McGrath \& Macmillan, 2000). The major difference lies at the entrepreneur's priorities. Social entrepreneurs are driven by the primacy of social goals, but they do not deny profit generation. Their economic activity and revenue streams serve their social mission. They apply market instruments within the social arena. Traditional entrepreneurs are driven by the primacy of profit generation, although they do often introduce positive social changes in their environment (e.g. by providing employment opportunities or various CSR initiatives), which are side-effects of their economic activity.

Differences in pursued goals pull organisational differences. The existing literature depicts very specific features of social enterprises that distinguish them in many aspects from strictly business-oriented ventures, cause internal tensions and present a set of very unique organisational challenges. First of all, they pursue social goals; although they are a part of a market economy, their mission and goals lie beyond it (Hausner et al., 2008). Social enterprises are highly contextual, embedded in local relationships and networks (Praszkier \& Nowak, 2012, p. 136) and highly dependent upon their various stakeholders (Stevenson et al., 2007). These include the founders, funders, partners, beneficiaries, suppliers, local community and authorities. The interests of these organisations are not always aligned (di Domenico et al., 2010). Social enterprises take numerous legal forms and cut across all sectors of the economy (Defourny \& Nyssens, 2010). Their financial resources are varied ranging from private capital and profit generation to government subsidies and charity donations (Leś, 2008). What's more, its customers are often not the sources of their revenue and their profit distribution is highly limited (Defourny \& Nyssens, 2010).

Authors point out that social entrepreneurs respond in fundamentally different ways to adverse contextual conditions than their commercial counterparts. They are cooperative, participative and inclusive rather that rival in character (Short et al., 2009). These features are also reflected in their management style. As observed by Praszkier and Nowak (2012) social enterprises often rely on a new type of leadership, which the authors refer to as "empowering leadership" characterized by a high level of social empathy, focused on activating the potential of social groups and communities. These leaders assume the role of facilitators and enablers rather than "front men" of their organisations.

The coexisting normative definitions are numerous. The most common set of criteria depicting the characteristics of social enterprises are: the centrality of social mission, fragmented heterogeneous financing, blending social and commercial approaches, dispersed governance and stakeholder-dependence. In order to further distinguish the distinctive features of social entrepreneurship, to understand their nature and origin, it is useful to adapt an opportunity lens. This will enable to focus on the heart of the entrepreneurial act and to study the origins of social opportunity ventures. 


\section{Opportunity as Unit of SE Analysis}

Opportunity is referred to as the dominant thread in current mainstream entrepreneurship research, both individual and firm-level (Venkataram et al., 2012). According to Stevenson and Jarillo (1990) the pursue of opportunity, defines the ability of the individual, as well as the organisation to be entrepreneurial. Contemporary coexisting convictions regarding entrepreneurship are rather completing than competing, all referring to the identification, evaluation and pursuit of opportunity (Stevenson \& Jarillo, 1990; Jones \& Butler, 1992; Shane \& Venkataram, 2000).

Early conceptualizations of opportunity define them as situations in which new goods, services, raw materials and organizing methods can be introduced and sold at greater than their cost of production process (Casson, 1982). As Schumpeter (1934) elaborated, economies operate in a constant state of disequilibrium. Technological, political, social, regulatory, and other types of changes offer a continuous supply of new information about different ways to use resources and create wealth. By making it possible to transform resources into a more valuable form, new information can alter the value of resources and, therefore, the resources' proper equilibrium price. Because information is imperfectly distributed, all players in the market do not simultaneously acquire new information. Some players obtain information before others about resources lying fallow, new discoveries being made, or new markets being created. Those that obtain new information before others can purchase resources at below their equilibrium value and earn an entrepreneurial profit by recombining the resources and then selling them (Schumpeter, 1934). This suggests that time is an important aspects of opportunity exploitations and that early movers are more likely to succeed.

Taken these early findings, opportunities can come in various forms, yet their prerequisite is information asymmetry across time and space (Drucker, 1985). Information asymmetry can be related, for example, to weak institutional structures in developing economies. Information gaps can present an opportunity for entrepreneurs and stimulate them to compete in environments where they hold the advantage of superior access to information. Opportunities often occur due to political or regulatory shifts. Institutional or legal transitions, such as privatization processes in post-communist countries or new public management schemes offered numerous opportunities for social entrepreneurs.

Authors still disagree whether opportunities are objective or subjective phenomena. Shane and Venkataram (2000) argue that, although the recognition of opportunity is a subjective process, opportunities themselves are objective phenomena, that are not known to all people at all times. An opposing argument developed by others suggest that opportunities may be also created rather than discovered (Li, 2013). Opportunity creation may be driven by subjective beliefs and actions, rather than objective factors. According to some, it is human beings who bring life and meaning to opportunities, as without them opportunities are non-existent. Both positions hold strong arguments in this discussion and might completing rather than competing, taken the vast array of opportunity sources.

Shane (2000) offers a typology of opportunities, based on whether they rely on completely new combinations of means-ends or optimize existing ones. He refers to those two situations as to Schumpeterian and Kirznerian opportunities respectively. This distinction has been followed in later years by other authors and researchers have established that 
these two perspectives explain to existence of different types of opportunities that can be both present in an economy at the same time (Shane \& Venkataraman, 2000), yet they may have different effects on the economic activity of the entrepreneur and bear different effects on the economy.

Schumpeterian opportunities result from disequilibrating forces and result in disrupting the existing system. They break away from existing knowledge and rely primarily on new knowledge and innovative ideas. Schumpeterian opportunities make the accumulation of evidence for their value and duration difficult. As a result, they are more risk sensitive and represent high profit potential (Aldrich \& Kenworthy, 1999). Schumpeterian opportunities rely on imagination and creativity and as such, they are rather created than identified, since they usually result in a brand new opportunity space and a new market.

Kirznerian opportunities, on the other hand, result from equilibrating forces and bring the economy closer to equilibrium. They rely on existing information, are not very innovative and replicate exiting organisational forms and established ways of doing things (Shane, 2000). Kirznerian opportunities emerge because prior decision makers made errors or omissions that have created surpluses or shortages. As such they are idiosyncratic, characteristic to an individual market situation (Shane, 2000). As such, Kirznerian opportunities are rather identified than created and involve observation and analytical skills.

All opportunities, despite their type and source have two important features: value and longevity (Shane, 2000). The value of opportunity is expressed in the belief that its expected profit will be larger than the opportunity cost of other alternatives (Kirzner, 1997). Again, opportunity value is not an objective phenomenon as it is based on subjective judgment and refers to the future. Even if two entrepreneurs might both identify an opportunity for internationalization, they are very likely to give that opportunity different value. In his early research Kirzner (1973) observed that that the process of discovery of opportunities requires entrepreneurs to guess customer' expectations about a variety of things. People make decisions on objective as well as subjective basis, often difficult or impossible to measure. Judging these expectations is therefore a highly subjective process.

Another feature of opportunities is their limited duration. Because entrepreneurial opportunities depend on asymmetries of information and beliefs, eventually, they become less profitable or even cost inefficient to pursue. This is for two prime reasons. First, as opportunities are exploited, information diffuses to other members of society who can imitate the entrepreneur and competition increases. Firms that enter foreign markets and generate high profits are usually followed by other entrants. When the entry rate of additional entrepreneurs reaches a level at which the benefits from new entrants exceeds the cost, the incentive for people to pursue the opportunity is reduced, as observed early on by Schumpeter (1934). Second, the exploitation of opportunity provides information to resources providers about the value of the resources that they possess and leads them to raise resource prices over time, in order to capture some of the profit (Kirzner, 1997).

Taken all of the above into reflect, opportunities in social entrepreneurship context can be defined as situations in which new mean-ends combinations in socio-economic environments can be created or optimized and that hold value over a limited amount of time. OBV of SE conceptualizes SE as the behavioural processes associated with the creation and exchange of value through the identification and exploitation of opportunities that lie on the overlap of social and economic sectors. OBV perspective adapts a process-oriented 
approach to social entrepreneurship, in which antecedents of opportunity and path dependence are relevant to our understanding of opportunity dynamics.

\section{RESULTS AND DISCUSSION}

\section{Theoretical Antecedents of Opportunity in Social Entrepreneurship Context}

The main question addressed hereafter is: what determines the identification and exploitation of social entrepreneurship opportunities? This study through an integrative literature review has conceptualized four antecedents of SE opportunity.

The first identified element of any SE opportunity is the social problem. Social entrepreneurs go beyond the marketplace and turn their attention to the social arena to identify their venture opportunities. Sources of their opportunities often lie within the social disequilibrium and refer to social problems. The notion that social problems can be perceived as sources of entrepreneurial opportunities is new and unexplored. This stream of research refers specifically to social entrepreneurship. Social problems have been defined by sociology literature twofold: (i) as acts and conditions that violate norms and values presents in a society, and (ii) as societally induced conditions that cause psychic and material suffering for any segment of the population (Eitzen et al., 2010, p. 10). Norm violations refer to the discrepancy between socially accepted standards and reality, such as homelessness, poverty or racial discrimination. As such, what is defined as a social problem differs by audience and by time (for example slavery or women rights). Opportunities refer to a certain time and space. Therefore, social problems by nature are subjective, but they do refer to objective reality. This line of thought resonates with the earlier presented view that although the recognition of opportunity is a subjective process, opportunities themselves are objective phenomena (Shane \& Venkataraman, 2000).

The second conceptualized element of SE opportunity is information. It has been established by OBV of entrepreneurship literature that possession of necessary information can be impacted most by the entrepreneur's prior knowledge and experience and his social networks. Prior experience, both business and non-business related, provides the entrepreneur with various information and knowledge. These bunks of knowledge coupled with new observations and information can take on new meaning and transform into new value. Knowledge building is a dynamic constructivist process that cannot be planned or foreseen. OBV of entrepreneurship builds on Hayek's view of new knowledge construction (Hayek, 1945). Opportunity development in the light of that theory, is a creative process in which the entrepreneur develops new ideas by recombining dispersed bits of incomplete knowledge that is spread among people, places and time, in novel ways that serve to create new value.

The second factor of information acquisition is social ties. It is an obvious observation that people gain access to information through interactions with other people. The structure of an entrepreneur's social networks determine what kind of information they receive, in terms of both quantity and quality. The strength of their social ties and their intensity will also determine the speed of the receipt of that information. Ties to a variety of different people enhances opportunity discovery since diversity of information is unlikely to occurs in homogenous networks (Battilana, 2006). Authors found that networks 
provide entrepreneurs with greater access to information and improve the quality, relevance and timeliness of that information (Adler \& Kwon, 2002). An extensive social resource base that allows entrepreneurs to discover opportunities more quickly through their network of relationships appears to be critical for social entrepreneurship, taken the limited durability of opportunities. In the context of social entrepreneurship network range stand out as a key feature of established networks. Network range refers to the number of unique knowledge pools (networks) with which the entrepreneur is directly connected (Adler \& Kwon, 2002). The more these pools are diverse and set in different social and business settings, the better.

The third antecedent conceptualized in the proposed model is social awareness which builds on cognitive abilities of the individual. In order to develop an opportunity, the entrepreneur has to combine and transform the possessed information in new ways. Differences in cognitive processing among people can influence this transformation process and thus individual propensity to identify opportunity. Some people are better than other at understanding causal links, categorizing information or have a bigger imagination.

Shane (2003) depicted four broad categories underlying the cognitive abilities critical in opportunity recognition: intelligence, perceptive ability, creativity and not seeking risks. The author quotes studies which suggest that differences among people in their intellectual capacity influence their likelihood of opportunity discovery. A person's general intelligence measured by their IQ is correlated in numerous longitudinal studies with the discovery of more valuable opportunities. Perceptive ability is a critical cognitive skill, since opportunity discovery always involves identification, absorption and analysis of information. Similarly creativity, since opportunities rely on novel solutions to open-ended questions. Shane quotes ample research which confirms that creativity is a cognitive ability, which enhances the chance of opportunity discovery. The fourth component of important cognitive abilities listed by Shane is not seeing risks. This property of individuals refers to the interpretation of information. Some people in new information and new ideas will mainly see risks, others will mainly see opportunities. Environmental changes and uncertainty evoke panic in some people, while excitement in others. Opportunity discovery cannot be stifled by risk aversion.

Certain people exhibiting the possession of these four fundamental cognitive properties will engage the information and experience they possess to identify or create social entrepreneurship opportunities. These are entrepreneurs. Yet literature suggests that social entrepreneurs share distinctive features that surpass the above mentioned cognitive skills and refer to social awareness, directing the entrepreneur's attention towards the social arena and pushing him to pursue social goals (Christensen et al., 2006; Curtis, 2007).

Social entrepreneurship theory does suggest a line of scientific pursue signalling the affective element of SE antecedents. Numerous papers have emphasized the role of compassion in individual-opportunity nexus dynamics (Miller \& Breton-Miller, 2014) claiming that the process of social entrepreneurship opportunity recognition is embedded in a configuration of individual dispositions, motivations and cognition patterns related to compassion (Dees, 2007). Compassion encourages and channels the engagement of cognition processes towards social problem identification and socially oriented ventures. Compassion has been identifies as one of the most distinctive features of social entrepreneurs, 
distinguishing them from other forms. As depicted earlier in the paper, commercial entrepreneurship and social entrepreneurship share many similarities. However, the latter's focus on social mission alongside market-based instruments separates them from all other ventures. Social entrepreneurship literature consistently points to the theoretical importance of compassion (Mair \& Marti, 2006; Shaw \& Carter, 2007), as a unique motivator of social entrepreneurship, placing the emphasis on the other, rather than on personal gains. Compassion creates a distinct motivational and driving force that compliments traditional theories of entrepreneurship.

Whereas compassion will enable the entrepreneur to recognize a social problem, sociological imagination will enable him to critically assess that problem, identify societal patterns behind it and search for solutions. Sociological imagination is a cognitive individual-level meta-structure which combines an openness to and awareness of diversity across social groups and problems with a propensity and ability to synthesize across this diversity. According to Eitzen and Smith (2003, p. 8), individuals who possess sociological imagination: (i) are willing and able to view the social world from the perspective of others, (ii) are capable of perceiving, analysing, and decoding social environments and societal patterns, (iii) can accurately identify effective actions in the social environment, and (iv) possess the behavioural flexibility and discipline to act appropriately. Sociological imagination is associated rather with the system-blame approach, than person-blame approach of social problems and thus with the will to find solutions and act upon them.

Since compassion and sociological imagination are cognitive abilities involving absorption and transformation of information, it appears critical to the process of opportunity identification in SE contexts. Both of these properties are built on intellectual, psychological and social capital building blocks that take time to develop and constantly evolve with time, as the entrepreneurs experience and relationships change. It is just to assume therefore, that individual's SE opportunity recognition is often a long-term process that can be traced back to prior knowledge and experiences, factors associated in research with shaping cognitive skills (Mitchell et al., 2002). Numerous prior events determine the patterns of a persons cognitive processes and their social awareness.

The fourth indispensible element conceptualized as antecedent of SE opportunity refers to the heart of entrepreneurial activity - entrepreneurial mindset. Entrepreneurial mindset, refers to the traits approach of entrepreneurship and has been conceptualized as a set of characteristics defining entrepreneurs through the prism of a passionate search and pursue of opportunity (McGrath \& MacMillan, 2000). According to Ireland, Hitt and Simon (2003) entrepreneurial mindset comprises of four components: (i) recognizing entrepreneurial opportunities, (ii) entrepreneurial alertness, (iii) real options logic and (iv) entrepreneurial framework. Recognizing entrepreneurial opportunity is specially defining for social entrepreneurs, for where most people see just social problems, they spot an opportunity (Light, 2008). Entrepreneurial alertness refers to superior insight that informs the pursuit of entrepreneurial opportunities. Real options logic is the ability to deal with the uncertainties inherent in recognizing and pursuing entrepreneurial opportunities, staying realistic and risk-aware. Entrepreneurial framework includes skills such as goal setting, resources acquisition and activation, and determining the timing to make the most of opportunities. SE ventures, as all entrepreneurial acts have a financial bottom line to reach and entrepreneurial decisions need to be well-grounded in market reality for the 
venture to be self-sustainable (Shuayto \& Miklovich, 2014). Therefore as in all entrepreneurial ventures, the entrepreneurial mindset determines whether the new identified opportunity will be exploited and turned into a new SE venture.

Figure 1 synthesises the above discussion and presents a holistic perspective on opportunity antecedents in SE context. In short, new ideas start with the identification of a social problem and with information based on prior knowledge and new information acquired through networks. Individual perception and judgment will determine the interpretation of the observed reality. Compassion and sociological imagination will enhance social awareness and opportunity alertness. Cognition processes can transform these information and scattered sources of knowledge into new ideas. Therefore diversified experiences and rich networks coupled with diverse cognitive abilities (including compassion and sociological imagination) of the entrepreneur can enhance the process transforming the social problem into an opportunity for entrepreneurial venture. An entrepreneurial mind will search for ways of employing market forces and instruments to transform the ailing social reality and push individuals towards market-based solutions to the identified social problems.

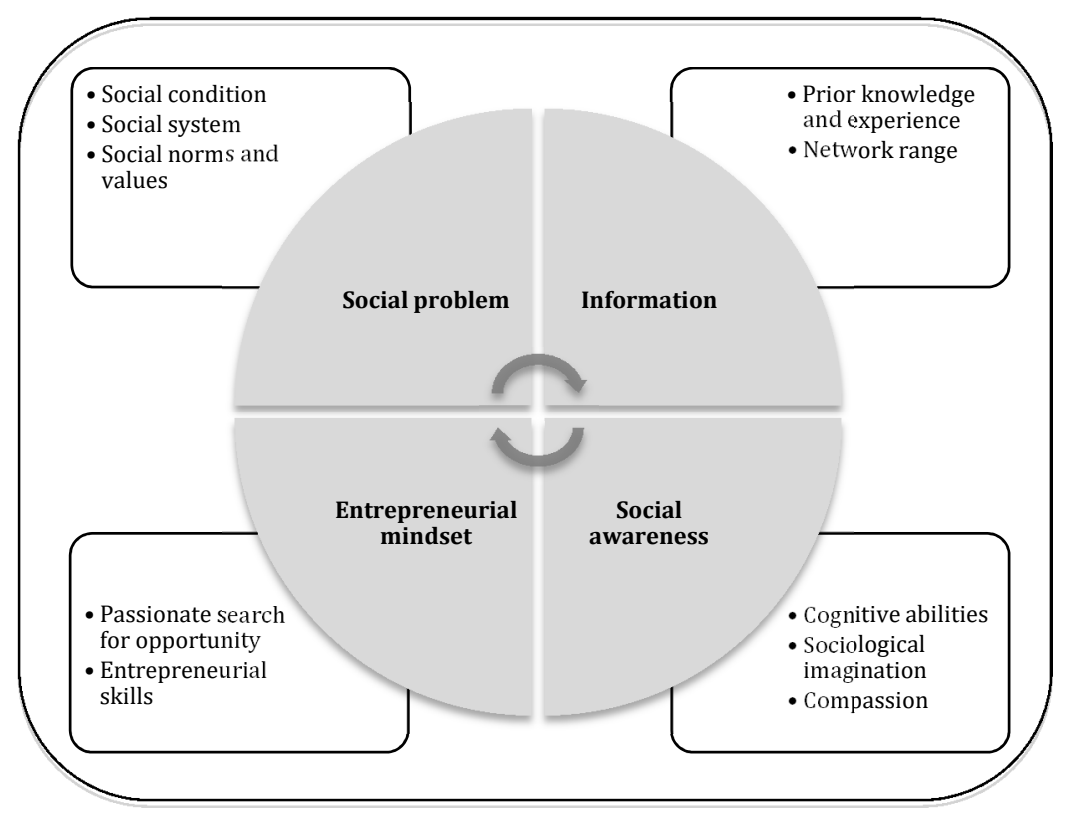

Figure 1. Antecedents of opportunity in SE context Source: own elaboration.

The above model of antecedents of SE opportunities opens up several potential inquiry paths to pursue. Further operationalisation and testing for interconnectivity is much advised. All of the variables of the model differ from one individual to another. Based on their earlier experience, individual cognitive properties and social ties, some entrepreneurs can acquire, utilize and process information quicker than others. They can therefore make quicker decisions about SE ventures. Grimes et al. (2013) suggested the need to study how these microprocesses interact with macro and mezzo level determinants, for 
example, when and how macro level determinants will stimulate or restrain these macroproceses involved in opportunity discovery and exploitation. As in traditional commercial entrepreneurial activity, the process of opportunity discovery and exploitation in SE context is highly determined by extrinsic factors, both macro level (environmental) and mezzo level (market specific). Environmental and market conditions will largely influence the entrepreneur's decision whether or nor not to pursue the identified opportunity (Damanpour et al., 2009; Rodriguez \& Guzman, 2013; Howaldt et al., 2015).

\section{CONCLUSIONS}

The study has established that social entrepreneurship occurs as a result of opportunity discovery and exploitation as answer to a social problem. Opportunities can be either created (Schumpeterian) and involve the creation of new means-ends frameworks (where others just see the social condition as a problem) or identified (Kirznerian) and optimize the existing means-ends frameworks. Either way, opportunity discovery is based on the transformation of knowledge and experience deriving from various social networks into new ideas and involves various cognitive abilities, among which in the context of SE compassion and sociological imagination appear to be critical. Entrepreneurial mindset is a prerequisite for successful opportunity pursue.

By tracking the process of opportunity discovery and identifying its antecedents, the study hopes to advance our understanding of social entrepreneurship, its distinctive features, differentiating them form other types of entrepreneurial acts.

This study hopes to contribute to the discussion devoted to opportunity-based approach to social entrepreneurship. It synthesizes fragmented pieces of research from the domains of social entrepreneurship, mainstream entrepreneurship and social problems theory and proposes a model of social entrepreneurship opportunity antecedents. The model exposes the role of time in opportunity development suggesting that opportunity recognition is a path dependent process. The model developed in the paper incorporates antecedents of opportunities that lead to opportunity recognition, and emphasizes the role of compassion and sociological imagination. The proposed model brings together state-of-the-art research and extends it by providing a deeper understanding of the entrepreneurial opportunity in SE context. Hopefully, the model can serve as a useful lens for hypotheses formulation and testing within the research domain of social entrepreneurship.

\section{REFERENCES}

Adler, P. S., \& Kwon, S. W. (2002). Social capital: Prospects for a new concept. Academy of Management Review, 27(1), 17-40.

Aldrich, H. E., \& Kenworthy, A. (1999). The accidental entrepreneur: Campbellian antinomies and organizational foundings. Variations in organization science: In honor of Donald Campbell ,1933.

Babbie, E. (2012). The Practice of Social Research. 13th ed., Belmont, CA: Wadsworth Cengage Learning.

Battilana, J. (2006). Agency and institutions: The enabling role of individuals' social position. Organization, 13(5), 653-676. 
Battilana, J., \& Lee, M. (2014). Advancing Research on Hybrid Organizing, The Academy of Management Annals, 8(1), 397-441.

Bull, M. (2008). Challenging tensions: critical, theoretical and empirical perspectives on social enterprise. International Journal of Entrepreneurial Behavior and Research, 14(5), 268-275.

Casson, M. (1982). The Entrepreneur: An Economic Theory. Rowman \& Littlefield.

Christensen, C. M., Baumann, H., Ruggles, R., \& Sadtler, T. M. (2006). Disruptive innovation for social change, Harvard Business Review, 84(12), 94-101.

Curtis, T. (2007). Finding that grit makes a pearl. A critical re-reading of research into social enterprise. International Journal of Entrepreneurial Behavior and Research, 14(5), 276-290.

Damanpour, F., Walker, R., \& Avellaneda, C. (2009). Combinative effects of innovation types and organizational performance: a longitudinal study of service organizations, Journal of Management Studies, 46(4), 650-675.

Dart, R. (2004). The legitimacy of social enterprise. Non-profit Management and Leadership, 14(4), 411-424.

Dees, J. G. (2007). Taking Social Entrepreneurship Seriously. Society, 44(3), 24-31.

Defourny, J., \& Nyssens, M. (2010). Conceptions of Social Enterprise and Social Entrepreneurship in Europe and the United States: Convergences and Divergences. Journal of Social Entrepreneurship, 1(1), 32-53.

Di Domenico, M., Haugh H., \& Tracey, P. (2010). Social Bricolage. Theorizing Social Value Creation in Social Enterprises. Entrepreneurship Theory and Practice, 34(4), 681-703.

Drucker, P. (1985). Innovation and entrepreneurship. Routledge.

Eitzen, D. S., Zinn, M. B., \& Smith, K. E. (2010). Social Problems. Pearson Education.

Grimes, M. G., McMullen, J. S., Vogus, T. J., \& Miller, T. L. (2013). Studying the origins of social entrepreneurship: compassion and the role of embedded agency. Academy of Management Review, 38(3), 460-463.

Hausner, J., Lauriusz, N., \& Mazur, S. (2008). Przedsiębiorstwo społeczne. Konceptualizacja, In J. Hausner (Ed.), Zarzqdzanie podmiotami ekonomii społecznej, skrypt 2, Krakow: MSAP UEK.

Hayek, F. A. (1945). The use of knowledge in society. The American Economic Review, 35(4), 519530.

Howaldt, J., Domanski, D., \& Schwarz, M. (2015). Rethinking Social Entrepreneurship: The Concept of Social Entrepreneurship under the Perspective of Socio-scientific Innovation Research. Journal of Creativity and Business Innovation, 1, 88-98.

Ireland, R. D., Hitt, M. A., \& Simon, D. G. (2003). A model of strategic entrepreneurship: The construct and its dimensions. Journal of Management, 29(3), 963-989.

Jones, G. R., \& Butler, J. E. (1992). Managing internal corporate entrepreneurship: An agency theory perspective. Journal of Management, 18(4), 733-749.

Kirzner, I. (1973). Competition and Entrepreneurship. Chicago, IL: University of Chicago Press.

Kirzner, I. M. (1997). How markets work: Disequilibrium, entrepreneurship and discovery (No. 133). Coronet Books Incorporated.

Leś, E. (2008). Nowa Ekonomia Społeczna. Wybrane Koncepcje, Trzeci Sektor, nr 2. Warszawa: Fundacja Instytut Spraw Publicznych.

Li, P. P. (2013). Entrepreneurship as a new context for trust research. Journal of Trust Research, 3(1), 1-10.

Light, P. C. (2008). The Search for Social Entrepreneurship. Washington, D.C.: Brookings Institution Press. 
McGrath, R. G., \& McMillan, I. C. (2000). The Entrepreneurial Mindset: Strategies for Continuously Creating Opportunity in an Age of Uncertainty. Boston, MA: Harvard Business School Press.

Miller, D., \& Breton-Miller, L. (2014). Deconstructing socioemotional wealth. Entrepreneurship Theory and Practice, 38(4), 713-720.

Mitchell, R. K., Busenitz L., Lant T., McDougall P. P., Morse E. A., \& Smith J. B. (2002). Toward a Theory of Entrepreneurial Cognition: Rethinking the People Side of Entrepreneurship Research. Entrepreneurship Theory and Practice, 27(2), 93-104.

Mair, J., \& Marti, I. (2006). Social Entrepreneurship Research: a source of explanations, prediction and delight. Journal of World Business, 41(1), 36-44.

Praszkier, R., \& Nowak, A. (2012). Przedsiębiorczość społeczna. Teoria i praktyka. Warszawa: Wolters Kluwer.

Rodriguez, M. J., \& Guzman, C. (2013). Innovation in social economy firms. Management Decisions, 51(5), 986-998.

Shane, S. A. (2000). A General Theory of Entrepreneurship: The Individual-opportunity Nexus. Edward Elgar Publishing.

Shane, S., \& Venkataraman, S. (2000). The promise of entrepreneurship as a field of research. Academy of Management Review, 25(1), 217-226.

Shaw, E., \& Carter, S. (2007). Social entrepreneurship: Theoretical antecedents and empirical analysis of entrepreneurial processes and outcomes. Journal of Small Business and Enterprise Development, 14(3), 418-434.

Schumpeter, J. (1934), Capitalism, Socialism, and Democracy. New York: Harper \& Row.

Short, J. C., Moss, T. W., \& Lumpkin, G. T. (2009). Research in Social Entrepreneurship: Past Contributions and Future Opportunities. Strategic Entrepreneurship Journal, 3, 161-194.

Shuayto, N., \& Miklovich, P. A. (2014). Creating organizational sustainability in social enterprises: the use of evidence-based positioning and market orientation. Review of Business and Finance Studies, 5(2), 109-116.

Stevenson, H. H., \& Jarillo, J. C. (1990). A paradigm of entrepreneurship: Entrepreneurial management. Strategic Management Journal, 11(5), 17-27.

Stevenson, H., We-Skillern, J., Austin, J., \& Leonard, E. H. (2007). Entrepreneurship in the Social Sector. London: Sage Publications.

Stryjan, J. (2004). The Practice of Social Entrepreneurship. In J. Targalski (Ed.), Entrepreneurship, Employment and Beyond. Kraków: Wydawnictwo Uniwersytetu Ekonomicznego w Krakowie.

Venkataraman, S., Sarasvathy, S. D., Dew, N., \& Forster, W. R. (2012). Reflections on the 2010 AMR decade award: Whither the promise? Moving forward with entrepreneurship as a science of the artificial. Academy of Management Review, 37(1), 21-33.

Whittemore, R., \& Knafl, K. (2005). The integrative review. Journal of advanced nursing, 52(5), 546553.

Yunus, M. (2011). Przedsiębiorstwo społeczne. Kapitalizm dla ludzi. Warszawa: Concorda. 


\section{Author}

\section{Agnieszka Żur}

Assistant Professor of Entrepreneurship of the Department of Entrepreneurship and Innovation at the Faculty of Economics and International Relations of the Cracow University of Economics (Poland). PhD in management (corporate entrepreneurship). Her current research interests include social entrepreneurship and socially engaged teaching and learning. Author of publications on corporate entrepreneurship and social entrepreneurship. Extensive experience in entrepreneurship and management teaching. Certified trainer and academic OxCam tutor. Member of Academy of Management since 2010. Guest lecturer for Grand Valley State University (Grand Rapids, USA), Western Michigan University (Kalamazoo, USA), Durham University, University of College London and Luton University (Great Britain), Sodertorn University (Stockholm, Sweden).

\section{Correspondence to:}

Agnieszka Żur, PhD

Cracow University of Economics

Faculty of Economics and International Relations

Department of Entrepreneurship and Innovation

31-510 Kraków, ul. Rakowicka 27

zura@uek.krakow.pl

\section{Acknowledgements and Financial Disclosure}

The article came into being within the statutory research project no. 054/WE$\mathrm{KPI} / 02 / 2015 / \mathrm{S} / 5054$ entitled "Inclusive Entrepreneurship: Contemporary Challenges and Development Perspectives" financed by the Ministry of Science and Higher Education of the Republic of Poland with the funds allocated to development of research potential of the Faculty of Economics and International Relations of the Cracow University of Economics.

\section{Copyright and License}

This article is published under the terms of the Creative Commons Attribution - NonCommercial - NoDerivs (CC BY-NC-ND 3.0) License http://creativecommons.org/licenses/by-nc-nd/3.0/

Published by the Centre for Strategic and International Entrepreneurship - Krakow, Poland 